\title{
Seismic risk assessment of the Ignalina NPP refuelling machine
}

\author{
R. Bausys ${ }^{1}$, G. Dundulis ${ }^{2}$, R. Kacianauskas ${ }^{1}$, D. Markauskas ${ }^{1}$, \\ S. Sliaupa ${ }^{3}$, E. Stupak ${ }^{1} \&$ S. Rimkevicius ${ }^{2}$ \\ ${ }^{I}$ Vilnius Gediminas Technical University, Lithuania \\ ${ }^{2}$ Lithuanian Energy Institute, Lithuania \\ ${ }^{3}$ Institute of Geology \& Geography, Lithuania
}

\begin{abstract}
The Ignalina NPP operates a RBMK type reactor. An important characteristic of the RBMK reactor is its online refuelling. The refuelling is carried out using the refuelling machine at a time of reactor operation. The refuelling machine is situated in the hall located above the reactor. The refuelling machine is supported and moved by a girder crane. The dropping dawn of the refuelling machine bears high risk to its integrity and reactor core functioning. One of risk scenarios considers impact of an earthquake on the plant. As a part of it, it is essentially important to carry out a global seismic assessment of the refuelling machine.

The seismic assessment of the support of refuelling machine is presented in this paper. The response of the reactor building to an earthquake was considered in the seismic analysis. The recently updated free field response spectra for the Ignalina NPP site were applied. The 3D thin-walled FE model of the reactor building was used for analysis. The 5\% damping was applied in calculation of the secondary response spectra of the refuelling machine. The response spectra of the acceleration and displacement of the supports of the refuelling machine were examined. The modelling was run for three different positions of the refuelling machine, i.e. at an initial position (waiting mode), at a position of unloading fuel assemblies and at a position of transportation.
\end{abstract}

Keywords: nuclear power plant, seismic analysis, finite element method, instructure spectra. 


\section{Introduction}

The Ignalina Nuclear Power Plant operates two graphite moderated, boiling water, multichannel RBMK-1500 reactors. This is the most advanced version of the RBMK design series (actually the only two of this type that were built). "RBMK" is a Russian acronym for "Channelized Large Power Reactor" [1]. It differs from the other reactor types. The refuelling of the RBMK type reactors is carried out under normal operation and nominal reactor power. Refuelling at full reactor power is accomplished by means of the refuelling machine. The refuelling machine performs operational and safety-related tasks. The safety tasks are as follows:

- $\quad$ unloading fuel assemblies with damaged cladding;

- $\quad$ on -load refuelling of channels with a leaking upper seal;

- replacing fuel assemblies with process plugs in channels with flow disturbances.

The refuelling machine is supported and moved by a girder crane. The refuelling machine schematically is presented in Figure 1.

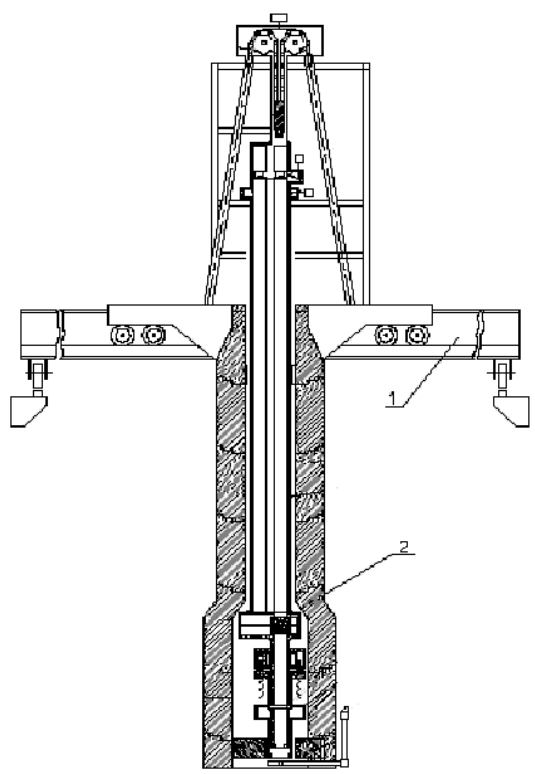

Figure 1: General view of refuelling machine, 1 - crane, 2 - refuelling machine.

The refuelling machine is located in the reactor hall. The refuelling machine service areas are as follows:

a. the refuelling machine storage area;

b. a practice and a calibration area (this area is used for adjustment and testing of the refuelling machine); 
c. the spent fuel reception area;

d. a repair area for replacement of damaged fuel caskets.

During the earthquake, the refuelling machine may be destabilised and drop dawn causing damage to the refuelling machine and reactor core. The global seismic evaluation of the refuelling machine is important in assessment of the reactor safety. The safe operation of the refuelling machine is important not only during the reactor operation, but also when it is stopped. The unloading of the fuel from shutdown reactor takes several years.

The Ignalina NPP is located in the western part of the East-European platform, at the transition between the two large-scale structural features, i.e. the Baltic depression and the Mazury-Belarus high [2-4]. A number of tectonic faults were identified by detailed geological-geophysical mapping in the Ignalina NPP area that may potentially induce the seismic event.

The seismic dynamic stability analysis of the Ignalina NPP building is performed using the BRIGADE/Plus code [5] in the present study. The response spectra of the support of the refuelling machine were calculated separately for the refuelling machine storage area, spent fuel reception area and transportation area. The design basis earthquake of the Ignalina NPP, the modelling of the reactor building and the modelling of the refuelling machine are described in three chapters of the paper. In the next chapter the results of the seismic assessment of the refuelling machine are discussed. The conclusions are made in the final chapter based on the performed analysis.

\section{Design basis earthquake of INPP}

The Baltic region is considered as an aseismic or of very low seismic activity. However, available data indicate that rather strong earthquakes took place in a past. The oldest historical record dates back 1303, when the strong earthquake shook Prussia (Kaliningrad District) and destroyed most of the timber houses. The seismic activity is distributed unevenly in the Baltic region. The maximum activity is confined to the central Latvia characterized by most intense faulting of the earth's crust cored by the largest-scale Liepaja-Saldus fault zone crossing the country from the east to the west $[2,3]$.

The closest to Ignalina NPP seismic event took place in Daugavpils area 35 $\mathrm{km}$ to the North-East of the Ignalina NPP in 1908.12.29. The intensity is $\mathrm{I}_{\mathrm{o}}=6-7$ (noise resembling gun-shot, apertures on the surface 3-4 inches wide, and fractures in building walls), estimated $\mathrm{M}_{\mathrm{L}}=4.6$, the hypocentral depth is of 10 $\mathrm{km}$. The epicentre is confined to the fault trending North West-South East. Furthermore, this event is related to the central part of the recent uplift attaining $4 \mathrm{~mm} / \mathrm{a}$, which is the highest value registered in the Baltic region [6]. Ignalina NPP is located on the South - West flank of this neotectonic uplift. A number of the different-scale tectonic lineaments were identified in the Ignalina NPP area. A few faults are essentially distinct in the sedimentary cover and underlying crystalline basement. Furthermore, these major tectonic features show recent activity of the horizontal and vertical movements [6]. Therefore, the potential 
near-field seismic events should be considered in the seismic risk assessment of the plant.

The Design Basis Earthquake was recently updated for the Ignalina NPP site [2] following the IAEA recommendations [7] and specifically the USSR Standards (PN AE-G-5-006-87). In present analysis the Design Basis Earthquake of the Ignalina NPP was assumed as strong as $I_{0}=7.5 \mathrm{~Hz}$. The free-field response spectra of the Ignalina NPP were derived using the deterministic approach [2], the peak ground acceleration was calculated as high as $166 \mathrm{~cm} / \mathrm{s}^{2}$. These spectra were used as the input seismic load in the seismic analysis of the reactor building.

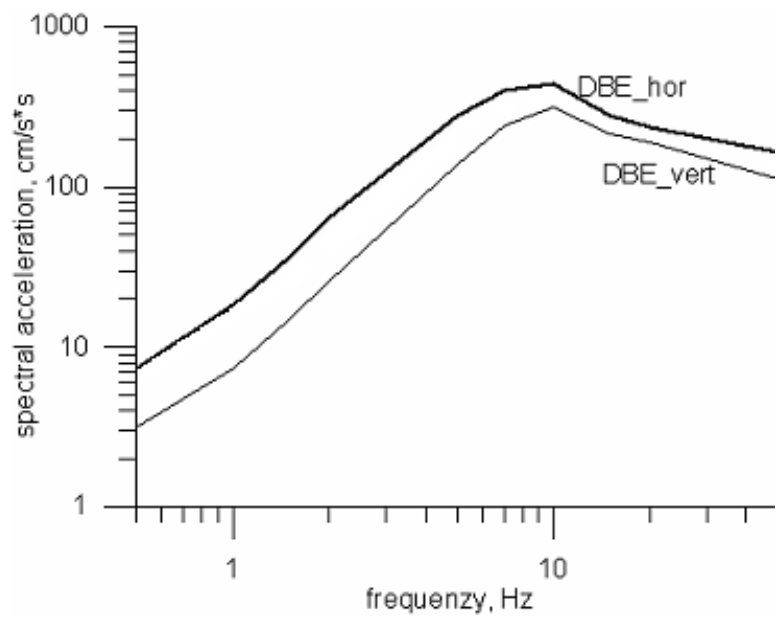

Figure 2: Free-field response spectra of Ignalina NPP Design Basis Earthquake $(5 \%$ damping, horizontal and vertical motion components).

\section{Ignalina NPP building model}

The Ignalina NPP unit 2 consists of five buildings [1]. They are located close to each other, but have separate foundations. Therefore these buildings are considered separately in the seismic analysis. The reactor building containing the refuelling machine was selected for structural seismic analysis. The crosssection of the reactor building with main components is presented in Figure 3.

The reactor building contains an RBMK-1500 reactor (pos. 1) with a main circulation circuit (pos. 3, 4, and 5). The accident localisation, in which the main circulation circuit is located, is adjacent to the reactor core. The hall above the reactor is a large workspace housing the refuelling machine (pos. 2). The spentfuel storage pond is situated in an adjacent hall, but separated from the reactor hall. The reactor compartment consists of a rectilinear structure, the horizontal cross-section of which is $90 \mathrm{~m} \times 90 \mathrm{~m}$ and a height of about $63 \mathrm{~m}$. 
The FE model of the Ignalina NPP reactor building was created using the Brigade/Plus pre-processor [5]. Element type S4R [8] is used in the model of the reactor building walls and slabs. Element type S4R is a fully integrated, generalpurpose, finite-membrane-strain shell element.

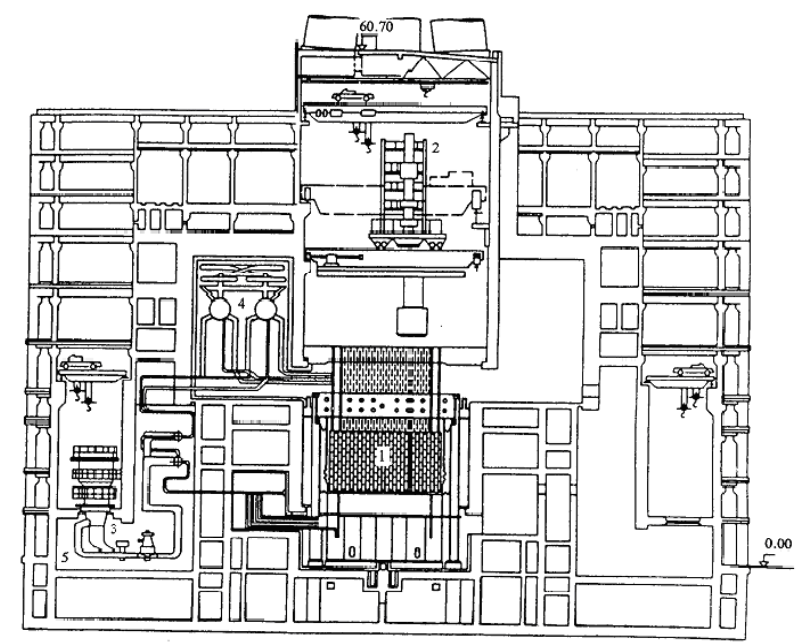

Figure 3: Cross-section of the reactor building with main components: 1 - reactor, 2 - refuelling machine, 3 - main circulation pump, 4 - separator drum, 5 - MCP pipelines.

The monolithic reinforced concrete construction and prefabricated parts of the main compartments of reactor building were included in the model. The prefabricated parts of the auxiliary compartments of reactor building were removed in the model. The following main equipment located in the reactor building and prefabricated concrete parts of the auxiliary compartments of the reactor building represent concentrated masses in the FE model of Ignalina NPP building (see Figure 3):

- mass of the reactor (pos. 1);

- mass of Main Circulation Pumps (pos. 3);

- mass of Drum Separators (DS) and piping located in the DS room (pos. 4);

- mass of the water in the condensing pools;

- mass of the removed prefabricated reinforced concrete structures of building.

The FE model of the Ignalina NPP reactor building is presented in Figure 4. This is a fixed-based model for dynamic analysis.

The masses of the removed prefabricated reinforced concrete wall structures are applied in a form of consistence masses, while masses of equipment are modelled as lumped masses and associated rotational inertia masses. 
The concrete properties used for the seismic analysis were obtained from building norms [9]. The value of Young's modulus of reinforced concrete is increased by factor 1.2 due to dynamic effects.

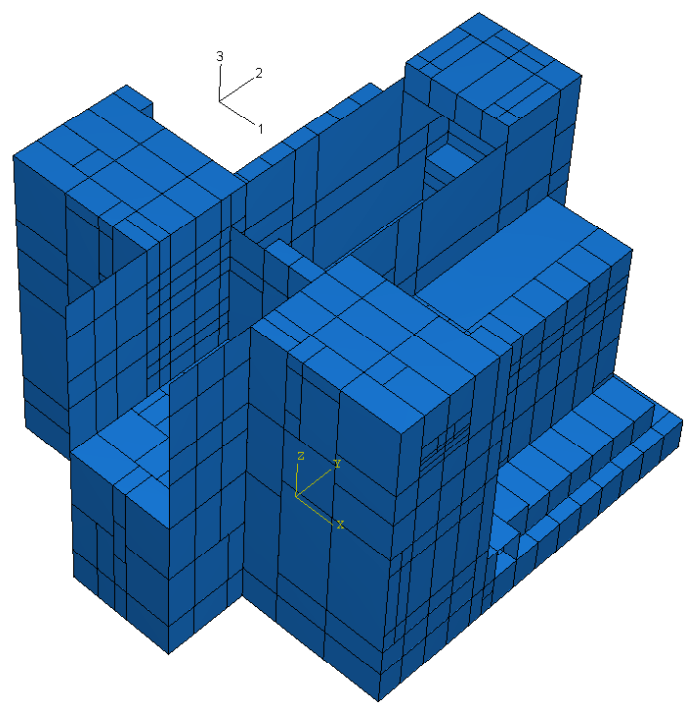

Figure 4: Geometrical model of the Ignalina NPP building.

\section{Modelling of the refuelling machine}

Refuelling machine is considered as dynamic subsystem, structure of which should be considered independently on the structure of the building. This model assumes uncoupled dynamic behaviour of machine and the building. In framework of this assumption, the mass of the machine is considered as an external mass affecting dynamic behaviour of the building structure, while evaluation of the seismic loads within machine structure would be considered as a secondary problem.

The working area of the refuelling machine, locations of it in the model and location of in-structure points are presented in Figure 5. Mass of the refuelling machine including mass of the moving crane is $450000 \mathrm{~kg}$ [10]. It is modelled as lumped mass. Vertically, the mass is located at the level $z=36.0 \mathrm{~m}$ of the moving crane (Figure 5(a)). Horizontally, crane moves in the South-North direction. The working area is restricted by position $y=42.0 \mathrm{~m}$ and by position $y=90.0$ above the reactor hall by baseline walls (Figure $5(\mathrm{~b})$ ). The lumped mass is attached in the centre of the crane beam and defined by the coordinate $x=0$ in the FE model (24/2, Figure 5(a) and (b)).

The seismic assessment of refuelling machine is carried out in refuelling machine storage area, spent fuel reception area and transportation area. Therefore three positions of the refuelling machine were fixed for modelling purposes as following (Figure 5(b)): 
- $\quad$ at storage position $(y=54 \mathrm{~m})$;

- at spent fuel reception position $(y=78 \mathrm{~m})$;

- at transportation position - selected position between storage and spent fuel reception $\operatorname{areas}(\mathrm{y}=66 \mathrm{~m})$.

Assessment of the seismic risk is focussed to the behaviour of the crane rail. The accelerations of the rail serve the base for evaluation of dynamic loads of the machine structure, while implements are important for evaluation of integrity and maintenance of the building-crane-machine system. The corresponding horizontal (East-West) in-structure response spectra were of key interest.

The location coordinates of the crane rail supports on the wall structure are $z=36 \mathrm{~m}$ and $x= \pm 12.0 \mathrm{~m}$ (Figure 5(a)) and b)). Four characteristic points along the machine working area on the wall structure are chosen for modelling purposes. Location coordinates of the analysed points 1, 2, 3, and 4 are respectively $y_{1}=\mathrm{y}-6, y_{2}=\mathrm{y}-3, y_{3}=\mathrm{y}+3$ and $y_{4}=\mathrm{y}+6$ (Figure 5(b)), where $\mathrm{y}$ is the coordinate of the refuelling machine position.

The mass of the refuelling machine was added in the discrete rigid point that is located in the mass centre of this machine and was connected with the wall of the reactor compartment by rigid constraints. Constraints are attached to the wall in a form of the line segment at the level o the crane rail $\mathrm{z}=36 \mathrm{~m}$. The segment length is taken to be with of the crane vehicle and is equal to $12.0 \mathrm{~m}$. The graphic illustration of the model is presented in Figure 6.

\section{Results and discussion}

The analysis was performed in the frequency domain and the floor response spectra at the supports of refuelling machine were determined. Vertical and horizontal (East-West direction) floor response spectra were calculated using free-field ground response spectra. The horizontal floor response spectra at two positions (storage and spent fuel reception) of refuelling machine are presented in Figure 7. The highest acceleration values are obtained for $5 \mathrm{~Hz}$ frequency equalling $3.1 \mathrm{~g}$. The influence of the position of refuelling machine on the maximum acceleration is illustrated in Figure 8. The highest acceleration was identified at the storage position $(\mathrm{y}=48 \mathrm{~m})$ of refuelling machine.

The horizontal (East-West) displacements at two positions of refuelling machine (storage and spent fuel reception) are presented in Figure 9. The maximum value of the displacement was defined for $5 \mathrm{~Hz}$ and equals to $0.037 \mathrm{~m}$. The influence of the position of refuelling machine on the displacement was evaluated. The maximum displacement of supports of refuelling machine was obtained for the storage position ( $\mathrm{y}=48 \mathrm{~m}$, Figure 10). The differences of the displacement of supporting points of the girder crane of refuelling machine reaches $0.074 \mathrm{~m}(2 * 0.037)$. The distance between girders of crane is $22.16 \mathrm{~m}$ (see Figure 5(a)). The possibility of dropping of the refuelling machine is small in case of the seismic event. 


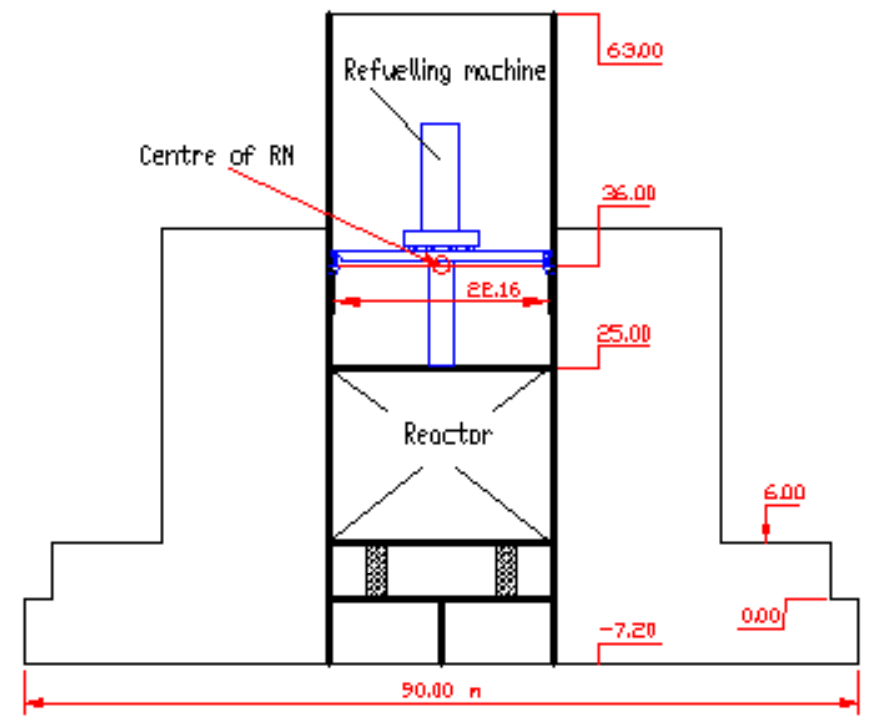

(a)

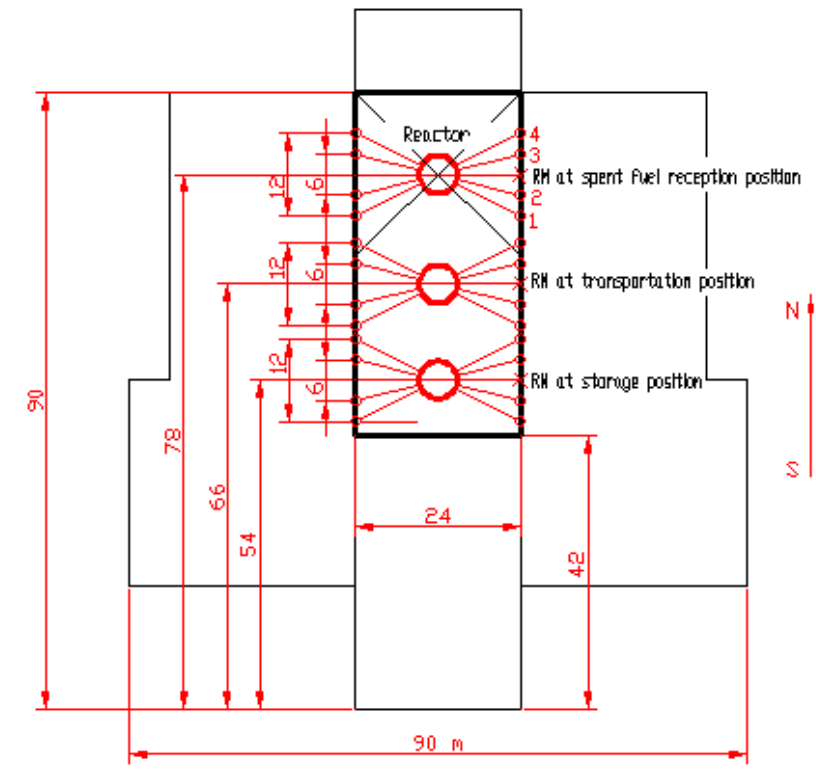

(b)

Figure 5: Schematic illustration of the reactor building with RM: (a) crosssection of the reactor building through axis of reactor, (b) layout of the building above of reactor at level $36 \mathrm{~m}$. 


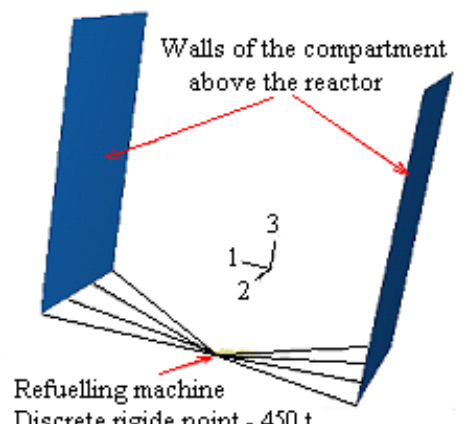

Discrete rigide point - $450 \mathrm{t}$

Figure 6: Modelling of mass of the refuelling machine.

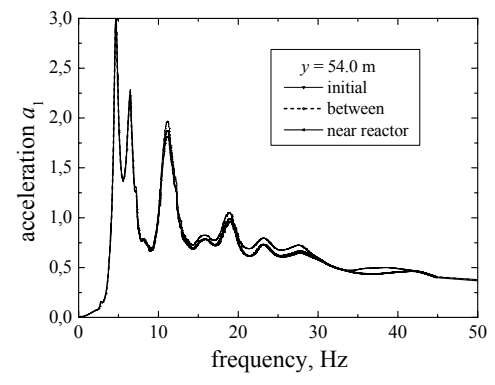

(a)

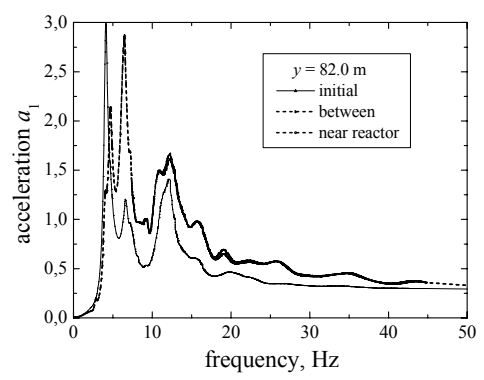

(b)

Figure 7: Horizontal acceleration floor response spectra at refuelling machine support: (a) at storage position, (b) at spent fuel reception position.

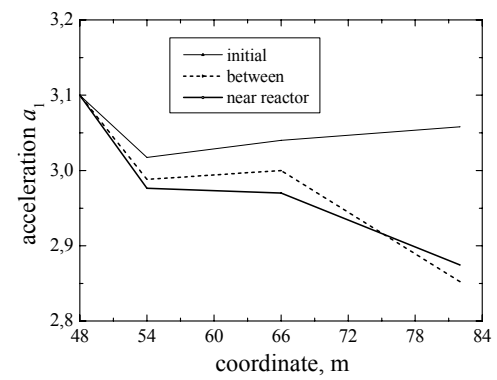

Figure 8: Variation of the horizontal acceleration floor response spectra with refuelling machine support position. 


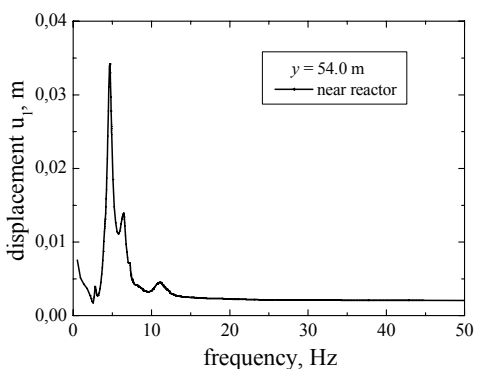

(a)

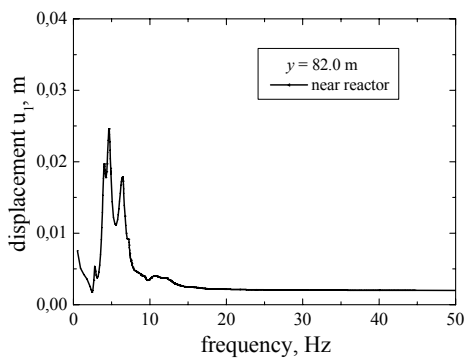

(b)

Figure 9: Horizontal displacement floor response spectra at refuelling machine support: (a) at storage position, (b) at spent fuel reception position.

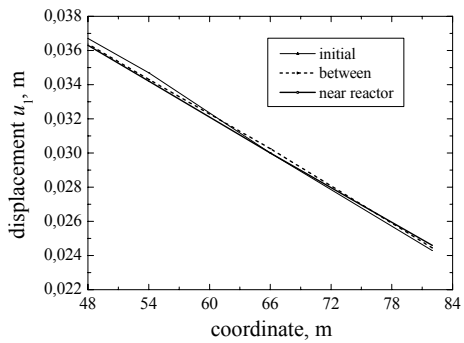

Figure 10: Variation of the horizontal displacement floor response spectra with refuelling machine support position.

\section{Concluding remarks}

The detailed 3D thin-walled finite element model of Ignalina NPP was applied for the seismic analysis of the refuelling machine. The in-structure response spectra of the accelerations and displacements of the supporting points of the refuelling machine are calculated using free-field ground response spectra of the Design Basis Earthquake. These response spectra were defined for three positions of the refuelling machine - at the storage position, at the spent fuel reception position and at the transportation position. The highest acceleration and displacement values were obtained for the storage position of the refuelling machine.

The differences of the displacement of supporting points at girder crane of the refuelling machine can reach $0.074 \mathrm{~m}$. The possibility of the collapse of the refuelling machine is small in case of the seismic event. 


\section{Acknowledgments}

The study was supported by Lithuanian Science Foundation. The authors also would like to express gratitude to the administration and technical staff of Ignalina NPP for providing information regarding operational procedures and operational data.

\section{References}

[1] Almenas, K., Kaliatka, A. and Uspuras, E., Ignalina RBMK-1500. A source Book, extended and updated version, Ignalina Safety Analysis Group, Lithuanian Energy Institute, 1998.

[2] S. Sliaupa, R. Kacianauskas, D. Markauskas, G. Dundulis and E. Uspuras. Design Basis Earthquake of the Ignalina Nuclear Power Plant. Geology, 2 (54), pp. 19-30, 2006.

[3] Sliaupa, S., Impact of last glaciation on stress regime and fault activity of the Baltic region. Geologija, 39, pp. 20-34, 2002.

[4] Marcinkevicius, V., Report of integrated geological-hydrogeological and engineering geology mapping at the scale of 1:50 000 of Druksiai area. Vilnius, Geological Survey of Lithuania, 1995.

[5] BRIGADE/Plus Version 1.2. User's Manual, Scanscot Technology AB, 2003.

[6] Zakarevicius A. Investigation of the recent movements earths crust in the territory of the Lithuania. Summary of research report presented for habilitation. Vilnius, Technika, 1999, 35 p.

[7] International Atomic Energy Agency. Seismic Design and Qualification for Nuclear Power Plants. Safety Guide No. NS-G-1.6, IAEA, Vienna, 2003.

[8] ABAQUS Version 6.4. Analysis User's Manual, ABAQUS, Inc., 2003.

[9] Norms and Rules for Buildings SNiP 2.03.01-84. (in Russian).

[10] RBMK-1500 technical description. Ignalina NPP, 1985. 